DOI 10.22363/2312-9220-2019-24-4-765-775

Research article

UDC 654.19(075.8)

BBC 76.031

\title{
Cyberprotest: new media and the new social movement in Indonesia
}

\author{
Munadhil A. Muqsith, Valerii L. Muzykant, Ksenia E. Kuzmenkova \\ Peoples' Friendship University of Russia (RUDN University) \\ 10 Miklukho-Maklaya St., bldg. 2, Moscow, 117198, Russian Federation
}

This paper aims to write the phenomenon of cyberprotest through new media in Indonesia. The development of new media caused changes in the pattern of social movements. This paper tries to explain how the design campaign of activists of the National Coalition to Rejects The Draft Bill of Music (RNTL RUUP) initiated by the Government of Indonesia. They consider this Draft Bill of Music will threaten freedom of expression in music in the future. Activists mobilized the protest movement through the \#TolakRUUPermusikan and \#Bersama BatalkanRUUPermusikan through online petitions, websites, Instagram, and Twitter.

Keywords: new media; new social movement; The Draft Bill of Music

\section{Introduction}

Social media has become an essential part of Indonesian society, recorded 150 million people in Indonesia as active users of social media [19]. The increasing interest of users of social networking sites (SNS) is due to the ease of connecting two individuals in a very intimate interpersonal, but also successfully connecting people to form group and forums from political to social issues [3]. E-mail, web sites, chat rooms, blogs, and bulletin boards enable efficient communication, organization, and even deliberation within new social movements of any size [4].

New social movements are formed through cohesion between the development of the internet and communication technology in the world. R. Singh views the new social movement as a form of mirror reflection from the image of a new society whose movement is ongoing. Therefore, this movement marks a new paradigm of collective action, an alternative model of culture and society, and a new self-awareness from communities about their future. The new social movement can be treated as a reflection of the cultural rebellion of contemporary individuals who

(C) Muqsith M.A., Muzykant V.L., Kuzmenkova K.E., 2019

This work is licensed under a Creative Commons Attribution 4.0 International License https://creativecommons.org/licenses/by/4.0/ 
oppose the increasing mechanization of the system of control and supervision by the state towards society [9].

In Indonesia, new social movements are forming changes in political partition and activism. Y. Nugroho and S. Syarief argue that new social movements utilizing SNS have succeeded in influencing Indonesia's political order. For example, social movements in 2009 through SNS raised support for "Koin Prita" then "Dukung Bibit-Candra." After that, a new social movement grew into a trend towards public participation and became a force of government pressure along with a few examples: "Satinah," "Bubarkan FPI," "Aksi Bela Islam 212," "Dukung Ahok," and the latest is movement to support "Clean Indonesia, President Reject Revision UU KPK!" [5]. This activity does not only take place in cyberspace but appears on the surface as demonstrations and donations by collecting money. In social movements on the issues of Prita, Satinah, FPI, Ahok, Reject Revision of the KPK Bill through an online petition (Change.org) in addition to other SNS.

This paper tries to provide an explanation of how the social movement strategy pattern of the National Coalition to Reject the Draft Bill of Music, henceforth will be shortened - RNTL RUUP, in Indonesia, which rejects the enactment of the Draft Bill of Music by the Indonesian House of Representatives by mobilizing political participation and activism with the hashtag \#TolakRUUPermusikan and \#Bersama BatalkanRUUPermusikan through various SNS platforms, began from making online petitions (Change.org), Instagram, Twitter. They consider the government's policy to issue the Draft Bill of Music threatening the issue of freedom of artistic expression in music.

\section{New media and new social movement}

This paper will try to prove the hypothesis of how new media creates a new paradigm of social movement patterns to mobilize the masses because of the need for faster and more modern collective action. According to Diani and Eyerman, quoting Duyvendak and Kompmas, to speak of a social movement generally four elements should be present: (1) a network of organisations, (2) a shared collective identity, (3) mobilizing people to join, mostly unconventional actions (4) to obtain social or political goals [6].

Scholars research the increasing role of the internet and social media in democracy because it successfully facilitates the social and political involvement of citizens [7]. Research on the Arab Spring revolution by Howard and friends in 2011, for example, shows that hundreds of thousands to millions of mobilized times are connected through Facebook, Twitter, and YouTube. For instance, during the Egyptian uprising in 2011, the week before President Mubarak's resignation, the rate of tweets about protests increased to 230,000 per day [8]. Protests via the Facebook platform are even more viral. In 2010, protests were seen on the 'We All Khaled Said' Facebook page, created in June 2010 to protest the death of Said, a middle-class Egyptian youth caused by the police. The Facebook page was then visited by hundreds of thousands of people and commented on and 'liked' the posting of the content [10]. 
Given the broad reach of communication through social media channels, crucial changes seem to occur in the distribution of media power, that is, "in the way, social reality itself is defined or named". Activists seem to be less dependent on mainstream media such as television and newspapers, to influence public communication. Z. Tufekci added that, "the relationship of "power dependence' between the media and social movement actors has been fundamentally changed." So that now, several studies above prove that mainstream media is no longer the only choice available to reach audiences the big one [11]. Examples of the Arab Spring revolution and the Occupation protests show that social media enables activists, under the right conditions, to communicate directly with an extensive public. From this perspective, social media emerges to resolve communication difficulties where activists have historically found themselves.

Another scholar said, social media not only allows user activity but powerfully directs this activity [12]. Through technological features, such as 'retweeting,' 'liking,' 'following,' and 'friending,' as well as algorithmic selection mechanisms, of course, the content is still exclusive. Through writing, videos, 'memes,' images, podcasts and hashtags, social platforms shape the way users can interact with each other through this platform. The forms of technology formation do not have to be in accordance with the interests of users, especially with the benefits of activists, but are first and foremost informed by the social media company's business model. However, of course, we have different features for each social media.

Social media has an essential role in raising participation and public opinion related to the issue of freedom of expression in music in Indonesia. According to Dannilla Riyadi (musician) in cnnindonesia.com on February 3, 2019 as well as initiators of the RNTL RUUP, assuming that there were at least 19 problematic articles submitted by the government in The Draft Bill of Music proposed by the government which threatened freedom of expression in music in Indonesia. Therefore, she initially initiated an online petition on the Change.org site with title \#TolakRUUPermusikan and \#BersamaBatalkanRUUPermusikan [13].

The RNTL RUUP also criticized The Draft Bill of Music because it contained 19 articles that were problematic because they overlapped with several existing Laws such as the Copyright Act, the Law on Hand-Over of Print and Recorded Works, and the ITE Law. More importantly, this Bill contradicts the Cultural Promotion Act and contradicts Article 28 of the 1945 Constitution, which upholds freedom of expression in a democratic country. In the release, Rara Sekar also explained that they found at least 19 problematic articles. Starting from the unclear editorial or the sound of the article, the unclear "who" and "what" is regulated, to the fundamental issues of guaranteeing freedom of expression in music [13].

At the same day, 260 musicians from the RNTL RUUP rejected the Draft Bill of Music. Various massive campaigns carried out by these musicians through social media networks such as Twitter, Instagram in the form of photos, videos, writings. One of them is from a famous singer like Jason Ranti, for example. He wrote, "Cheating. I made their music for they punish us. Cheat...". The next day, on February 4, 2019, a petition titled \#TolakRUUPermusikan was discussed, and it was recorded that it had been signed by 120 thousand accounts on the Change.org [14]. 
The interesting thing is that this social media activity has turned into real action through mass demonstrations directly to other regions in Indonesia. For example, on February 4, 2019, hundreds of musicians expressed their opinions directly at Cilandak Town Square, South Jakarta. Besides in Jakarta, on February 10, musicians in the city of Bogor also held a peaceful protest protesting the Draft Bill of Music in front of Tepas Lawang Salapan, Bogor City. In action, they challenged the contents of the Draft Bill of Music, which was considered to fetter freedom of expression and limit musicians to work. Activists in Surabaya also rejected the Draft Bill of Music proposed by the government. On February 18, 2019, several musicians and artists staged a peaceful rally in the city of Surabaya. They assess this Bill if passed, can hamper freedom and limit the creativity of musicians to work. In Pamekasan City, East Java also held a similar peace rally. On February 18, 2019, several musicians demanded the same thing, rejecting the Draft Bill of Music in front of the Pamekasan House of Representative. They considered the Bill as a threat to the future of music and freedom of expression. Besides, the action coordinator Indra said the Issue Bill would marginalize independent musicians and be in the interest of large industrial interests [13].

The impact of the RNTL RUUP campaign strategy through social media did not only increase in social media, in several regions in Indonesia; some groups of people continued their demands through a real demonstration movement. The author is interested in describing the pattern of their movement strategy to carry out campaigns through new media. This movement strategy pattern had previously been used in mobilizing other movements on issues such as Prita, Satinah, FPI, Ahok, Refusing to Revise the KPK Law. Through this strategy pattern, this leads to increased public participation and turns into real action through direct mass demonstrations.

Social media activities are interpreted as a movement strategy. Chandler, quoted by Singh said that strategy is the setting of long-term goals and objectives, as well as the direction of action and allocation of resources needed to achieve those goals and objectives. The use of social media is deliberately determined as a form of allocation of resources to achieve the objectives of the movement [9]. Acting as a strategy, social media activities are proven to be able to influence the type of real movements [1].

That capability is manifested in three ways, namely: 1) the division of problem definitions as the basis for forming a collective identity, 2) being able to mobilize members, 3 ) expanding the network by connecting a number of different organizations. In addition, social media benefits political activities by destroying state monopolies on the production of knowledge and information flow [2]. Information on social media is also able to reach national and international users. However, conventional technology is still needed to disseminate information from social media to the public who do not use social media.

Related to the selection of strategies in new social movements, Singh revealed the term binary social movements. A new social movement that focuses its strategy on the role of the reason (and collective action) and the role of reflection [9]. 
The part of the reason is in line with the ability of actors to mobilize resources. If related to W. Van De Donk previous thoughts, the formation of collective identity, mobilizing members, and network expansion are part of the work of reason's role in new social movement strategies [1]. If related to Lim's thinking, the way the actors of the movement produce knowledge and control the flow of information becomes part of the role of reflection in the new social movement strategy [2]. This research wants to see how social media accommodates the role of reason and reflection as part of the strategy movement \#TolakRUUPermusikan and \#BersamaBatalkanRUUPermusikan.

Furthermore, the real action is seen as part of a strategy to push the change of public issues into a political agenda. Thus, the continuation of social media activities becomes the writer's real action as a transformation of the movement's strategy. Not all social media activities can continue into a real movement for the sake of turning public issues into political agendas. Some of the factors driving the transformation of social media activities into real action are the combination of the use of social media with conventional media, establishing face-to-face interactions to solve problems of access to information due to the internet, as well as political opportunities. The movement can still have a strong grassroots base without being limited to actors who can only access the internet.

\section{Online petition (Change.org)}

Online petitions are channels that can be utilized by people who have concerns over specific issues or issues to propose policy changes related to those issues. One of the most popular online petitions is Change.org, as seen from the statistics displayed on the Change.org website. This is a petition platform for social change, with more than 265 million users globally. Every day, millions of people use Change.org to start, sign, and support petitions about issues that are important to their lives and communities, creating active campaigns that drive for real change.

According to Geron in 2018, Koening \& McLaughlin in Indonesia, Change. org is one of the popular online petitions. It was officially established in 2012 and is still actively promoting policy changes to the present. Change.org Indonesia facilitates users to initiate and gather support through online petition signing. As of December 31, 2018, there were already 5.4 million people registered in Indonesia on the Change.org portal.

The RNTL RUUP, as written above, was initiated by a female musician named Dannilla Riyadi. In the old https://www.change.org/p/my-tolakruupdiscussion-dprri it was written Danilla was also the person who started the petition with the title \#TolakRUUPermusikan. This petition was directed at the House of Representatives of the Republic of Indonesia as the initiator of the Draft Bill of Music [CITATION Cha19\11033].

On the page, Danilla wrote:

"The Draft Bill of Music is unnecessary and has the potential to repress musicians. O friends and music lovers in the country (Indonesia). Warm greetings! 
I am Dannila Riyadi, a representative of my friends from the National Coalition Rejecting the Draft Bill of Music, to jointly draft this petition."

Change.org has a good design and menu that can spread petitions made by people to spread to others quickly. There is a menu of how many have signed the petition and comments. In addition, there is a menu to spread this petition to Facebook and Facebook messenger. Another menu for sharing petitions is sending a friend's email and then tweeting to Twitter followers. Finally, there is a menu for copying the links of these petition sites to be shared on other digital platforms.

Until September 18, 2019, this petition has been completed and is considered victorious over its demands to the government; it has been recorded that 313,524 supporters who signed the petition rejected the Draft Bill of Music.

\section{Official website}

Everyone in this world needs a home. Not just for shelter and sleep at night. But also the shipping address sent something. So does the necessity of every organization or social movement to have an address on the internet. A website that functions and has the same tasks as our home in the real world. The RNTL RUUPP has an official website address - www.tolakruupermusikan.com

The RNTL RUPP website contains all the information needed about the movements of musicians rejecting the Draft Bill of Music. So everyone who wants to get information about this movement can be completed on this website. On this website, there is a menu about this movement, complete video content of the rejection campaign from musicians, activity photo galleries, and even provide a form for support, here is also information to support the petition on Change.org. With a good website appearance, The RNTL RUPP movement conveyed the number of members and the official address of this movement on other social media.

\section{Instagram}

Instagram became the social media with the most significant increase in the number of active users in the past four years. The number of active Instagram users jumped 23\% from 130 million users in June 2013 to 150 million per month in the fourth quarter of last year. Understanding Instagram according to B.D. Atmoko in his book "Instagram Handbook" is as follows: Instagram is a photo-sharing application that allows users to take photos, apply digital filters, and share them to various social networking services, including Instagram's own. From the author's analysis, Instagram's social media has an important role in existing

Instagram Features is a photo-sharing application that applies digital filters to change the appearance of photo effects, and share them with various social media services such as Facebook and Twitter, and includes Instagram itself. Instagram has five main menus which are all located at the bottom of the Instagram display. The menus are: 
1) The Home Page is the main page that displays the latest photos or videos from fellow users that have been followed. How to view pictures is by sliding the screen up like when scrolling a mouse on a computer, it will show the posts or content uploaded by users;

2) Explore is a display of popular photos that are most liked by Instagram users. Can be photographs and videos from famous artists or photos of stunning landscapes. Or photos that are of interest to the user;

3) News Feed is a feature that displays notifications or notifications of various activities performed by users. Newsfeeds have two types of tabs namely "following" which displays the latest activity on users that users have followed and "news" which displays the latest notifications on the activities of Instagram users on shared photos;

4) Profile is a page that can find out detailed information from users, both profiles of personal accounts and other users. This feature displays the number of photos and videos that have been uploaded, the number of following and followers;

5) Story is a window that displays photos and videos such as the home feature, but in this feature stories have a time limit to display, each story created by the user will be displayed for 24 hours and will be deleted by itself after time runs out. This feature looks more like short flashes to easily share moments.

In addition to the above features, there are several other features that can make a photo or video content uploaded to Instagram more interesting and meaningful, including:

1) captions or information to reinforce the character or message that the user wants to convey. Captions are created when creating a photo or video content to be posted;

2) hashtag is a symbol marked with a fence (\#). This feature makes it easy for users to find photos and videos on Instagram with a specific hashtag;

3) location feature is a feature that displays the location where the user took a photo.

As social media, many interactions occur in the Instagram application, so this application provides several activities that users can do on Instagram, as follows:

1) Follow means to follow, followers are followers from Instagram users, to follow or make friends with other users click to follow. The number of followers and followers who follow will be seen on the user's profile page;

2) Like is an icon where users can like pictures or videos on Instagram, thumbs up on Instagram is different from thumbs up on Facebook, thumbs up on Instagram is a heart symbol, likes or likes content is done by pressing the like button at the bottom of captions which is next to the comment or can be with a double tap on the content you like;

3) Comments are activities in giving thoughts through words. Users are free to give any comments to the photo, be it a suggestion, praise or criticism;

4) Mentions feature is to add or call other users, how to add an arroba (@) and enter the Instagram account name of that user. 
The RNTL RUUP utilizes its social movement campaigns through Instagram. Have an official account named @koalisinasionaltolakaruup.The RNTL RUUP official Instagram account has the largest follower of $19.9 \mathrm{~K}$, among other official social media. They have posted 165 times that contain photos and videos of movement activities. One of the contents posted by RNTL RUUP even likes 2,382 and 12 positive comments support.

\section{Twitter}

The emergence of social media as a communication media that produces social movements is becoming increasingly popular. Twitter, which appeared in 2006, has been used for political debate communication, crisis communication, marketing and cultural participation. The emergence of the use of social media for social movements began with the Arab Spring incident, protests of Egyptians published in "The New York Times". The protest through Twitter was also legitimized in the mass media and the media of citizens [15].

The use of Twitter for political discussion at local, regional and national levels of elections in Australia, protests and mobilization activities in Tunisia, Egypt and Yemen, and the Wikileaks case demonstrate Twitter's success in changing social life. By using '\#' symbols such as '\#ausvotes' for the 2010 Australian elections, '\#londonriots' for information coordination and political debate in London or '\#wikileaks' about the secrets of public officials, has become a phenomenon of the Twitter community [16].

In Mexico, Twitter also plays a role in influencing the government to make decisions and form relationships between the government, citizens, politicians, and various stakeholders. The younger generation has used young socially to communicate awareness, organize protests during the 2012 Mexican presidential election [17]. The use of active Twitter functions such as "tweeting" supports users to play an active role in making messages in social media. While passive use through "following other users" and "retweeting" is also important in spreading information to followers [18].

In Indonesia, the RNTL RUUP also utilizes its social movement campaigns via Twitter. Through their official@RNTLRUUP account, they campaign for their ideas. This account was only established in February 2019. The number of followers reached 1,519 with 167 tweets.

\section{Conclusion}

The National Coalition Movement Rejects the Draft Bill of Music (RNTL RUUP) is understood as a new social movement because of the demands of the movement around the struggle for freedom of expression that will threaten musicians are going forward. Through certification, and the grip of other corporations. Even though many independent musicians already exist. The new social movement is no longer new in the use of social media as a channel to mobilize public participation and en- 
courage public opinion. Previously, there were many other social movements such as in East Asia, the Philippines, and others who had already used social media as a media against the government.

Within the framework of the thinking of new social movements, social media is proven to be able to accommodate reasoning and reflection strategies. The reasoning strategy is demonstrated through the practice of creating and distributing content on social media which is nothing but the process of defining their own identity, who is their opponent, and who is their friend. While the reflection strategy is the formation of public opinion (the knowledge network) through weak ties of actors, as a result, opinions can circulate quickly and widely. Social media then appears as if it is the most effective strategy to reach support from grassroots communities amid the fact that not everyone is able to access social media.

Social media succeeded in transforming public issues into political agendas when able to build anger at the grassroots level through the reasoning and reflection of the actors of the movement, have a strong political commitment, establish real support with the local groups being defended, and continuously interact face to face in space real. Social media is not neutral. He is revolutionary, but not utopian. That is, it needs proper management in accordance with the character of every social media. In addition, social media cannot replace the role of conventional media, especially to solve challenges to access. Thus, a combination of both is still needed.

Social media can encourage democratic representation because it has successfully pushed public issues into a political agenda. This success occurs when social media activities can transform into real action. A number of concrete measures have been carried out, such as peaceful protests ranging from peace in Jakarta, Bogor, Surabaya, and Pamekasan.

Furthermore, this real action becomes part of the actor's strategy as an effort to encourage democratic representation, so that the sustainability of the strategy from social media activities to real action is understood as a form of movement strategy transformation. As for a number of factors driving the transformation of the movement strategy are the formation of strong ties between factors, combination with conventional media, and the presence of political opportunities. Hence the position of social media as a new social movement strategy facilitates the reasoning and reflection strategies of actors in mobilizing support. In addition, social media activities are able to encourage democratic representation when successfully transformed into concrete actions as a strategy to turn public issues into political agendas. This end was successful, because in the end, the Draft Bill of Music was withdrawn from the Indonesian parliament.

\section{References}

[1] Van De Donk W., Loader B.D., Nixon P.G., Rucht D. Cyberprotest: New Media, Citizens and Social Movements. Routledge, 2004.

[2] Lim M. Cyber-Urban Activism And The Political Change In Indonesia // Eastbound Journal. 2005. Vol. 1. 
[3] Gangopadhyay S. Introduction Digital Media: Emerging Issues. Kolkata: Suhrid, 2014.

[4] Bimber B., Flanagin A.J., Stohl C. Reconceptualizing Collective Action In The Contemporary Media Environment // Communication Theory. 2005. Vol. 15. Issue 4. Pp. 365-388.

[5] Nugroho Y., Syarief S. Beyond Click-Activism? New Media and Political Processes in Contemporary Indonesia. Friedrich-Ebert-Stiftung, 2012.

[6] Duyvendak J.W. Tussenverbeelding en macht: 25 jaar nieuwe sociale bewegingen in Nederland. Amsterdam, 1992.

[7] Enjolras B., Steen-Johnsen K., Wollebaek D. Social media and mobilization to offline demonstrations: transcending participatory divides? // New Media \& Society. Vol. 15. No. 6. Pp. 890-908.

[8] Howard P. N., Freelon D., Duffy A., Hussain M.M., Mari W., Mazaid M. Opening Closed Regimes: What Was the Role of Social Media During the Arab Spring? // SSRN Electronic Journal. 2011.

[9] Singh R. Teori-Teori Gerakan Sosial Baru // Jurnal Ilmu Sosial Transformatif. 2002. XI.

[10] Gerbaudo P. Tweets and the Streets: Social Media and Contemporary Activism. London: Pluto Press, 2012.

[11] Tufekci Z. "Not This One": Social Movements, the Attention Economy, and Microcelebrity Networked Activism // American Behavioral Scientist. 2013. Vol. 57. Pp. 848-870.

[12] Fuchs C. Foundations of Critical Media and Information Studies. New York: Routledge, 2011.

[13] Musisi Indonesia Galang Petisi Tolak RUU Permusikan // CNN Indonesia. 2019, 4 February. https://www.cnnindonesia.com/nasional/20190204050647-32-366172/musisiindonesia-galang-petisi-tolak-ruu-permusikan (accessed: 15.09.2019).

[14] Prabowo H. Melihat dari Dekat Musisi Berserikat dan Menentang RUU Permusikan // Titro.id. 2019, 4 February. https://tirto.id/melihat-dari-dekat-musisi-berserikat-dan-menentang-ruu-permusikan-dfSi (accessed: 16.09.2019).

[15] Harlow S., Thomas J. The Arab Spring. Overthrowing the Protest Paradigm? How The New York Times, Global Voices and Twitter Covered the Egyptian Revolution // International Journal of Communication. 2011. Vol. 5. https://ijoc.org/index.php/ijoc/article/ view/1239/611 (accessed: 30.11.2019).

[16] Bruns A., Burgess J. \#Ausvotes: how Twitter covered the 2010 Australian federal election // Communication, Politics and Culture. 2011. Vol. 44. No. 2. Pp. 37-56.

[17] Sandoval-Almazan R., Gil-Garcia J. Cyberactivism through Social Media: Twitter, YouTube, and the Mexican Political Movement "I'm Number 132" // Proceedings of the $46^{\text {th }}$ Hawaii International Conference on System Sciences. 2013. Pp. 1704-1713. doi: 10.1109/HICSS.2013.161.

[18] Ballard C. “What's happening”@twitter: a uses and gratifications approach: Master's Theses. University of Kentucky, 2011. P. 155.

\section{Article history:}

Received: 11 September 2019

Revised: 15 September 2019

Accepted: 12 October 2019

\section{For citation:}

Muqsith M.A., Muzykant V.L., Kuzmenkova K.E. (2019). Cyberprotest: new media and the new social movement in Indonesia. RUDN Journal of Studies in Literature and Journalism, 24(4), 765-775. http://dx.doi.org/10.22363/2312-9220-2019-24-4-765-775 


\title{
Bio notes:
}

Munadhil Abdul Muqsith, Ph.D student, Department of Mass Comunications, Peoples' Friendship University of Russia (RUDN University). E-mail: kmk-phil@yandex.ru

Valerii L. Muzykant, Doctor of Sociology, Professor, Department of Mass Communications, Peoples' Friendship University of Russia (RUDN University). E-mail: vmouzyka@mail.ru Ksenia E. Kuzmenkova, Assistant, Department of Mass Communications, Peoples' Friendship University of Russia (RUDN University). E-mail: kmk-phil@yandex.ru

Научная статья

\section{Киберпротест: новые медиа и новое социальное движение в Индонезии}

\author{
М.А. Муксит, В.Л. Музыкант, К.Е. Кузьменкова
}

Российский университет дружбы народов

Российская Федерачия, 117198, Москва, ул. Миклухо-Маклая, д. 10, корп. 2

Статья посвящена феномену киберпротеста в новых медиа Индонезии. Авторами предпринята попытка объяснить, каким образом удалось отклонить инициированный правительством Индонезии крупнейший проект, регулирующий музыкальное законодательство (RNTL RUUP - национальная коалиция за отклонение проекта). Законопроект о современной музыке, по мнению цифровых активистов, мог угрожать свободе в выражении музыкальных взглядов. С помощью социальных сетей, веб-сайтов и онлайнпетиций (\#TolakRUUPermusikan и \#BersamaBatalkanRUUPermusikan) было организовано эффективное движение протеста. Проект был отклонен.

Ключевые слова: новые медиа; социальные медиа; законопроект о музыке; Индонезия

\section{История статьи:}

Дата поступления в редакцию: 11 сентября 2019

Дата принятия к печати: 12 октября 2019

\section{Для цитирования:}

Муксит М.А., Музыкант В.Л., Кузьменкова К.Е. Киберпротест: новые медиа и новое социальное движение в Индонезии // Вестник Российского университета дружбы народов. Серия: Литературоведение. Журналистика. 2019. Т. 24. № 4. С. 765-775. http:// dx.doi.org/10.22363/2312-9220-2019-24-4-765-775

\section{Сведения об авторах:}

Мунадхил Абдул Муксит, аспирант кафедры массовых коммуникаций, Российский университет дружбы народов. E-mail: kmk-phil@yandex.ru

Музыкант Валерий Леонидович, доктор социологических наук, профессор кафедры массовых коммуникаций, Российский университет дружбы народов. E-mail: vmouzyka@mail.ru Кузьменкова Ксения Евгеньевна, преподаватель кафедры массовых коммуникаций, Российский университет дружбы народов. E-mail: kmk-phil@yandex.ru 